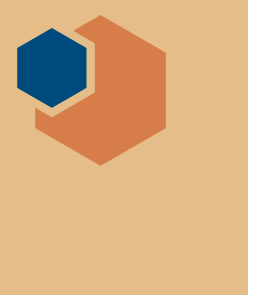

\section{China eliminates rare-earths quotas}

$\mathrm{C}$ hina's Ministry of Commerce eliminated the quota system for rare-earths exports starting in January 2015. These materials, some of which are considered critical in a broad range of high-tech applications, from consumer electronics and medical equipment to clean-energy and military applications, have been an area of scientific, industrial manufacturing, and government focus for several years.
The issues around rare-earth elements (REEs) are very complicated because of a number of contributing factors. International politics and economics play a large role in the price and availability of these commodities, but the properties of the materials themselves and the breadth of different types of deposits add a layer of complexity. According to Lawrence Meinert, Head of the Natural Resources
Rare-Earth Elements and Common Uses

\begin{tabular}{|c|c|c|c|}
\hline Element & Symbol & Classification & Uses \\
\hline Scandium & Sc & Light & $\begin{array}{l}\text { Lightweight aerospace components, armor } \\
\text { alloys }\end{array}$ \\
\hline Yttrium & Y & Heavy & $\begin{array}{l}\text { Lasers, high-strength materials, high- } \\
\text { temperature superconductors, high-temperature } \\
\text { ceramics, radar, superalloys }\end{array}$ \\
\hline Lanthanum & $\mathrm{La}$ & Light & $\begin{array}{l}\text { Hydrogen storage, nickel-lanthanum hydride } \\
\text { battery electrodes, optical lenses, phosphors, } \\
\text { fluid-cracking catalyst }\end{array}$ \\
\hline Cerium & $\mathrm{Ce}$ & Light & $\begin{array}{l}\text { Polishing powder, phosphors, superalloys, fluid- } \\
\text { cracking catalyst }\end{array}$ \\
\hline Praseodymium & $\operatorname{Pr}$ & Light & Magnets, lasers, x-ray scintillators \\
\hline Neodymium & $\mathrm{Nd}$ & Light & Magnets, lasers, glass pigments \\
\hline Promethium & Pm & Light & Batteries \\
\hline Samarium & Sm & Light & Magnets, lasers, phosphors \\
\hline Europium & Eu & Light & $\begin{array}{l}\text { Phosphors, lasers, lighting, nuclear physics } \\
\text { studies }\end{array}$ \\
\hline Gadolinium & $\mathrm{Gd}$ & Light & $\begin{array}{l}\text { Magnets, lasers, computer memory, } \\
\text { pharmaceutical tracers for MRI, neutron } \\
\text { capture, optics }\end{array}$ \\
\hline Terbium & $\mathrm{Tb}$ & Heavy & $\begin{array}{l}\text { Phosphors, lasers, lighting, sonar, x-ray } \\
\text { detectors, magnetostrictive alloys }\end{array}$ \\
\hline Dysprosium & Dy & Heavy & Magnets, lasers, halide lamps \\
\hline Holmium & Ho & Heavy & Magnets, lasers, materials \& nuclear research \\
\hline Erbium & Er & Heavy & Lasers, fiber optics, synthetic gems \\
\hline Thulium & Th & Heavy & X-ray machines, lasers, nuclear physics \\
\hline Ytterbium & $\mathrm{Yb}$ & Heavy & $\begin{array}{l}\text { Lasers, nuclear medicine, high strength alloys, } \\
\text { optics, pressure sensors }\end{array}$ \\
\hline Lutetium & Lu & Heavy & PET scan detectors, scintillometers \\
\hline
\end{tabular}

Program at the US Geological Survey, "Rare earths are not traded and sold as pure metals but rather in oxide, carbonate, or alloyed forms tailored to specific applications. They are also a niche market because while they are critical to achieve specific properties, most applications use very small amounts of these materials." The combination of these two factors means there is a very different pricing structure for REEs than for typical metals like gold, iron, copper, and aluminum, for example.

In addition, "rare earths are not all equal - there are some elements that are extremely important, but many others that are not," said Jack Lifton, Co-founding Principal at Technology Metals Research LLC. This fact further complicates the issue because even though some of the heavy REEs are the most critical, "most rare-earth deposits have more light rare earths than heavy rare earths, with the exact amounts varying depending on the mineralogy of the deposit," said Meinert. With these factors in mind, it is easy to see that talking about REEs as a single commodity provides a flawed view of a very complex situation.

Regardless of the oversimplification that often surrounds REEs, China has been the dominant supplier of both light and heavy REEs for the past several decades, accounting for over $90 \%$ of world production in 2013. In 2009, when the existing quotas were being reduced to lessen the outflow, China accounted for nearly $97 \%$ of the world's REE production. China cited conservation of its natural resources as well as environmental concerns associated with mining and production of REEs as the primary reasons behind imposing the more restrictive export quotas.

The restrictive nature of China's REE export quotas catalyzed efforts to reopen or develop new sources as well as implement recycling programs in a number of technology-producing countries. In the United States, several bills that address various aspects of reestablishing a domestic supply of REEs and other critical materials have been introduced in the last few sessions of Congress (the most recent of which was reported in the February 2014 issue of MRS Bulletin). 
To date, none of these bills has garnered enough support to pass into law.

The United States has also funded a number of initiatives and research programs to address domestic supplychain issues, improve critical materials recycling, and develop substitutes for critical materials. The Materials Genome Initiative (see MRS Bulletin, August 2012) and the Critical Materials Institute (see MRS Bulletin, April 2013) are two such efforts focused on addressing REEs and critical materials issues.

In the United Kingdom, the Natural Environment Research Council recently invested $£ 7$ million in a five-year program called Security of Supply of Mineral Resources (SoS Minerals) that has already funded a number of smaller grants focusing on elements that are considered critical for production and efficient use of energy (including REEs). A secondary round of projects is currently under consideration, with the aim to set up larger research programs between academia and industry that would further address supply issues for these critical materials.

In 2014, the European Commission (EC) published a list of 20 critical materials, including REEs. The EC and the European Union (EU) Framework 7 also co-fund EURARE, a five-year project to develop a sustainable exploitation scheme for Europe's REEs with a budget of nearly $€ 14$ million. In addition, a number of research projects funded across the EU partner with African, South American, and Asian countries to study and develop REE sources.

Other Asian nations have also invested significant government funds in REE research to find and exploit new resources. Japan and Vietnam partnered to establish the Rare Earth Research and Technology Transfer Centre, which has instituted programs focused on finding alternatives and recycling critical materials. South Korea has also established a technology center, the Korea Institute for Rare Metals, to support the development of rare metals resources and technology. While this list of nations involved in REE research programs is by no means complete, it clearly shows a very broad interest in these critical materials.
On the supply side, Molycorp Inc. reopened the mine and upgraded the processing facility at Mountain Pass in the United States and Lynas Corp. opened a mine in Mount Weld, Western Australia, and a processing plant in Malaysia. It is important to note however that both companies produce primarily light REEs. Other REE deposits across the globe contain levels of heavy REEs on par or greater than Chinese sources; however, according to Meinert and Lifton, there is no current shortage in rare-earths supply outside of China to drive new development.

The elimination of China's export quotas on REEs follows a March 2014 ruling by the World Trade Organization (WTO) that China's REE export restrictions breach its WTO obligations. The complaint, initially filed separately by the United States, Japan, and the EU in March 2012, was consolidated into one case and addressed not only REE export quotas but also export duties and trading rights on REEs, tungsten, and molybdenum. The complaint was supported by a number of third parties including Argentina, Australia, Brazil, Canada, Colombia, India, Indonesia, the Republic of Korea, Norway, Oman, Peru, the Russian Federation, the Kingdom of Saudi Arabia, Chinese Taipei, Turkey, and Vietnam.

The complainants in this case disputed China's claim that the restrictions were related to conservation of natural resources and pollution reduction, and argued instead that they were designed "to provide Chinese industries that produce downstream goods with protected access" to the materials (REEs, tungsten, and molybdenum). China unsuccessfully appealed the WTO ruling, which became final in August 2014. In September 2014, China announced its intention to revise its trade regulations to align with its WTO obligations within a reasonable period of time.

The elimination of export quotas for REEs was detailed in the Ministry's 2015 trade guidelines issued in December 2014. These materials are now subjected to an export licensing system, the effectiveness of which remains to be seen. Additionally, it is important to note that although the export quotas have been eliminated, China still plans to levy export tariffs on REEs for 2015. The continuation of these tariffs means China has not yet fully aligned its trade practices with WTO expectations.

Most REE experts agree that this policy change will have very little impact on the REE market and on scientists and industries depending on these materials. This is due in large part to the fact that there has been no real shortage in REE supplies in recent years. Despite the predicted lack of impact on science, Frances Wall, Associate Professor in Applied Mineralogy at the University of Exeter, points out a possible positive outcome, saying, "Hopefully [eliminating the quotas] will decrease the black market trade of rare earths and help China's efforts to lessen the environmental pollution caused by the rare-earth industry."

With regard to policy, Alan Hurd, Executive Advisor at Los Alamos National Laboratory, said, "Responsible mineral resources development is a national security need-depending on foreign sources for rare earths and other commodity metals can produce vulnerability that would be very difficult to address quickly due to the long lead times necessary to mine and produce some of these critical materials." Lifton added that a lot of emerging uses for REEs in the defense industry "may trigger interest in policy that would support a domestic rare-earths market."

On the science side, interest in REEs has fueled funding for a broad range of research projects. One possible outcome of China's reformed REE trading policy could be the loss of interest in these types of projects. But scientists, government officials, and critical materials experts alike agree that funding for rare-earths research is critical. Hurd summed it up: "While I view the elimination of quotas on China's rare-earths exports as a positive step in international diplomacy, it should not in any way halt efforts to diversify critical materials sources, find substitutes for these materials, and institute a recycling program to capture more value from the supplies we already have."

Jennifer A. Nekuda Malik 